\title{
EFFECT OF SELENITE ON THE TOTAL POLYPHENOL CONTENT AND ANTIOXIDATIVE ACTIVITY OF AQUEOUS AND ETHANOLIC EXTRACTS IN SPROUTS OF FOUR AGRONOMIC SPECIES
}

\author{
Efecto del selenio sobre el contenido total de polifenoles y la actividad antioxidante \\ de extractos acuosos y etanolicos en brotes de cuatro especies agronómicas \\ Yoshie Motomura ${ }^{1}$ Marjorie Reyes-Díaz ${ }^{2,3}$, Maria de la Luz Mora Gil ${ }^{2,3}$ \\ ${ }^{1}$ Program for the Senior Volunteer of the Japan International Cooperation Agency. \\ Universidad de La Frontera, Casilla 54-D, Temuco, Chile. \\ ${ }^{2}$ Instituto de Agroindustria, Universidad de La Frontera, Casilla 54-D, Temuco, Chile. \\ ${ }^{3}$ Centro de Ciencias y Biotecnología de Recursos Naturales, Universidad de La Frontera, \\ Casilla 54-D, Temuco, Chile. Corresponding author: mariluz@ufro.cl
}

Keywords: antioxidative activity; crop seedling; ethanolic extract; polyphenol; selenium.

\begin{abstract}
Sprouts from some agricultural plants grown under dark conditions are known to contain some functional food ingredients. Recently, great attention has been paid to foods with natural antioxidative ingredients for human health and animal feed. Among the functional food compounds, phenolics and polyphenols are the most desirable food bioactives due to their antioxidative activity. The aim of this study was to determine the differences between aqueous and ethanolic extracts and the effect of selenite on the polyphenol content, and whether the antioxidative activity of selenite-treated sprouts growing in Petri dishes is enhanced compared to non-treated ones. The total polyphenol content in aqueous extract and ethanolic extract increased significantly in wheat (3 times). In the selenite-treated sprouts of ryegrass and wheat, antioxidative activities in the ethanolic extracts increased significantly with the concentration of selenite ( 2 and 2.5 times, respectively). In the aqueous extracts, however, the effect of selenite on the antioxidative activities was less pronounced, with the exception of wheat (2.5 times). Based on our results, the sprouts of wheat grown with selenium under dark conditions and extracted with ethanol could be considered a potent and functional food ingredient or dietary food supplement for humans and animals because the selenium increased the total polyphenol content and antioxidative activity.
\end{abstract}


Palabras claves: actividad antioxidante; cultivo; extracto etanólico; polifenol; selenio.

\section{RESUMEN}

Brotes de algunas plantas agricolas que crecen bajo condiciones de oscuridad contienen algunos ingredientes alimenticios funcionales. Recientemente, los alimentos con ingredientes antioxidantes naturales han despertado gran interés en la salud humana y alimentación animal. Entre los compuestos funcionales de los alimentos, los fenoles y polifenoles son los compuestos bioactivos mas deseables debido a su actividad antioxidante. El objetivo de este estudio fue determinar las diferencias entre extractos acuosos y etanólicos y el efecto del selenio sobre el contenido de polifenoles y la actividad antioxidante de brotes de cuatro especies agronómicas. El contenido total de polifenoles en extractos acuosos y etanólicos incrementó significativamente (3 veces). La actividad antioxidante de extractos etanólicos de brotes de ballica y trigo tratados con selenio aumentó significativamente (2 y 2,5 veces, respectivamente). En el extracto acuoso, sin embargo, el efecto del selenio sobre la actividad antioxidante fue menos pronunciada, con excepción del trigo (2,5 veces). Basado en nuestros resultados, los brotes de trigo crecidos bajo condiciones de oscuridad, suplementados con selenio y extraídos con etanol podría ser considerado como un potente $\mathrm{y}$ funcional ingrediente o suplemento alimenticio en la dieta de humanos y animales porque el selenio aumentó el contenido de polifenoles totales y la actividad antioxidante.

\section{INTRODUCTION}

Some sprouts of beans, cereals and weeds - for example, mung beans, soy beans and alfalfa and buckwheat seedlings - grown under dark conditions are consumed as fresh vegetables by humans. Recently, great attention has been paid to foods with natural antioxidative ingredients for human health and animal feed. Among the functional food ingredients, phenolics and polyphenols are the most desirable food bioactives due to their antioxidant activity. Thus, numerous studies have evaluated the antioxidative activity of the polyphenolic components in fruits, vegetables, soybeans, herbs, teas, wines and medicinal plants (Kanner et al., 1994; Vinson et al., 1995; Wang et al., 1996; Sato et al., 1996; Pietta et al., 1998). For example, studies have shown that extracts from green tea leaves (Camellia sinensis) contain polyphenolic components with activity against a wide spectrum of microbes (Taylor et al., 2005). Furthermore, green tea also possesses various pharmacological properties which include antioxidative activity (Ho et al., 1992; Serafini et al., 1996; Koo and Cho, 2004).
In contrast, trace amounts of selenium are considered essential for growth and development in most organisms (Hu et al., 2003). Selenium is also known to be important as an antioxidant in humans and animals because glutathione peroxidase, a selenoenzyme, exhibits antioxidant activity capable of reducing reactive oxygen species (ROS) (Hartikainen and Xue, 1999; Hu et al., 2003). Some geographical areas including North America, Oceania, China, Chile and Northern Europe, are seleniumdeficient, which means that feed crops contain insufficient selenium to meet animal requirements (Gissel-Nielsen et al., 1984; Gupta and Watkinson, 1985; Johnsson, 1992; Gupta and Gupta, 2000; Wittwer et al., 2002; Cartes et al., 2005).

However, while almost all of the sprouts for vegetables are grown under dark conditions, most of the experiments on the effects of selenium on plants have been conducted under light conditions (Carlson et al., 1989; Carvalho et al., 2003; Kim et al., 2003). Thus, much less attention 
has been paid to the effect of selenium on polyphenol contents and the antioxidative activity of aqueous and ethanolic extracts of sprouts grown under dark conditions. This study was conducted to determine whether certain sprouts from agricultural plants treated with selenium and grown under dark conditions are useful as phenolics-enriched and antioxidative food supplements for humans and animals. The effect of selenite on the total polyphenol content and the antioxidative activity in aqueous and ethanolic extracts of the sprouts germinated under dark conditions were examined using four agronomic plants species.

\section{MATERIALS AND METHODS}

Chemicals: Selenite, Folin Ciocalteau reagent, sodium dodecyl sulfate and linoleic acid were purchased from Merck. DPPH (1,1-diphenyl-2-picrylhydrazyl) was obtained from Wako Pure Chemical Industries, Ltd., Japan. Trolox (6-hydroxy2,5,7,8- tetramethylchroman-2-carboxylic acid) was obtained from Sigma.

Plant materials: Certified seeds of red clover (Trifolium pretense L. cv. Tolten), ryegrass (Lolium hybridum, cv. Horizon), wheat (Triticum aestivum, cv. Dollinco) and oat (Avena sativa L. cv. Chaofen) were obtained from the laboratory of seeds at the Universidad de La Frontera, Temuco, Chile. Experimental solutions were prepared using selenite $\left(\mathrm{Na}_{2} \mathrm{SeO}_{3}\right)$ and distilled water to obtain final concentrations of $0,0.05,0.1$, $0.2,0.4,0.8$ and $1.0 \mathrm{mM}$. The $\mathrm{pH}$ of the selenite solution was approximately 6.0. Each Petri dish contained one piece of Whatman $\mathrm{N}^{\circ} 41$ filter paper, $9 \mathrm{~cm}$ in diameter, which was then treated with the appropriate solution. The volume of the solution added to each Petri dish was $4 \mathrm{~mL}$. Fifty seeds of red clover and ryegrass were placed in a Petri dish, and 25 seeds of wheat and peeled oat were used per Petri dish. All Petri dishes were wrapped with aluminum film, covered with a paper bag and placed in a dark chamber at $20^{\circ} \mathrm{C}$. Three replicates were used for each treatment.

Two weeks later, the germination percentage of seeds was examined and the fresh weight, sprout weight and sprout length of each seedling were measured. In this study, germination refers to the emergence of the radical through the seed coat. For the measurement of total polyphenol and radical scavenging effect, $0.2 \mathrm{~g}$ of fresh sprouts of ryegrass, wheat and oat were collected. Sprouts, cotyledons and roots were collected for red clover. These fresh materials were wrapped with aluminum film and stored at $-20^{\circ} \mathrm{C}$ under dark conditions until analysis. Three replicates were used for each treatment.

Preparation of the extracts: Fresh materials $(0.2 \mathrm{~g})$ were homogenized in 2 $\mathrm{mL}$ of water or ethanol (aqueous and ethanolic extracts, respectively). After centrifugation $(5000 \mathrm{rpm}, 10 \mathrm{~min}$, at room temperature), the supernatant was collected and stored at $-20^{\circ} \mathrm{C}$ until analysis.

Determination of total polyphenol content: The total polyphenol content of the ethanolic and aqueous extracts was determined based on the method described by Singleton et al. (1965), with minor modifications. The absorbance of the resulting blue color was measured spectrophotometrically at $760 \mathrm{~nm}$ at room temperature. Quantification was done on the basis of a standard curve of gallic acid. Results were expressed as gallic acid equivalents. The experiments were performed in triplicate.

Antioxidant assay by DPPH radical scavenging activity: The free radical scavenging effect in aqueous and ethanolic extracts was assessed by the decoloration of an ethanolic solution of DPPH according to the method of Chyau et al. (2006) with minor modifications. In this study, the absorbance was measured at $520 \mathrm{~nm}$. As a standard compound, Trolox was used, and the radical scavenging activity on DPPH was calculated as Trolox equivalents. The experiments were performed in triplicate. 


\begin{abstract}
Antioxidant assay by inhibition activity of lipid peroxidation: In the aqueous and ethanolic extracts of the sprouts, antioxidant activity was determined by measuring their protective action towards linoleic acid peroxidation in micelles of sodium dodecyl sulfate (Foti et al., 1996). Trolox was used as a standard and the inhibition of lipid peroxidation activity was calculated as Trolox equivalents. The experiments were performed in triplicate.
\end{abstract}

Statistical analysis: Two-way analyses of variance (ANOVA) was used to test the effects between species and selenite concentration on percentage of germination, total fresh weight, sprout weight, sprout length, total polyphenol substances, radical scavenging activity and inhibition activity of lipid peroxidation. A Tukey test was used to identify those values with significant differences. Sigma Stat 3.1 software (SPSS $^{\circledR}$ Inc., Chicago, IL, USA) was used for both analyses. Differences between the values $(P \leq 0.05)$ were determined.

\section{RESULTS AND DISCUSSION}

Germination and growth of sprouts Germination percentage was not affected at selenite concentrations less than $0.4 \mathrm{mM}$ in any plant species (Table 1). Germination percentage was only reduced by the selenite concentration above $0.8 \mathrm{mM}$ in red clover $(16 \%)$ and ryegrass $(10 \%)$. Germination percentage in wheat and oat were $100 \%$ in all selenite concentrations (Table 1). In the preliminary experiments, germination percentages were $84 \%$ (ryegrass), $64 \%$ (wheat) and $52 \%$ (oat) at $4 \mathrm{mM}$ of selenite. Over $40 \%$ of the wheat seeds germinated at $15 \mathrm{mM}$ of selenite (unpublished data). The effect of selenite in decreasing germination was in the order: red clover $>$ ryegrass $>$ wheat and oat. Total fresh weight (total weight of sprout, root and seed) was significantly reduced by the increase of selenite concentration in all plant species $(P \leq 0.05)$ (Table 2$)$. Relative reduction in fresh weight was highest in red clover (about $70 \%$ ), lowest in ryegrass,

Table 1. Effect of selenite on the percentage of germination in red clover, ryegrass, wheat and oat

Cuadro 1. Efecto del selenio sobre el porcentaje de germinación en trébol, ballica, trigo y avena*

\begin{tabular}{lccccccc}
\hline & \multicolumn{7}{c}{ Selenite concentration $(\mathrm{mM})$} \\
\cline { 2 - 8 } \multicolumn{1}{c}{ Species } & 0 & 0.05 & 0.1 & 0.2 & 0.4 & 0.8 & 1.0 \\
\hline Red clover & 100 & 100 & 100 & 100 & 100 & 96 & 84 \\
Ryegrass & 100 & 100 & 100 & 100 & 100 & 96 & 90 \\
Wheat & 100 & 100 & 100 & 100 & 100 & 100 & 100 \\
Oat & 100 & 100 & 100 & 100 & 100 & 100 & 100 \\
\hline
\end{tabular}

The values are the average of 3 replicates for each treatment. 


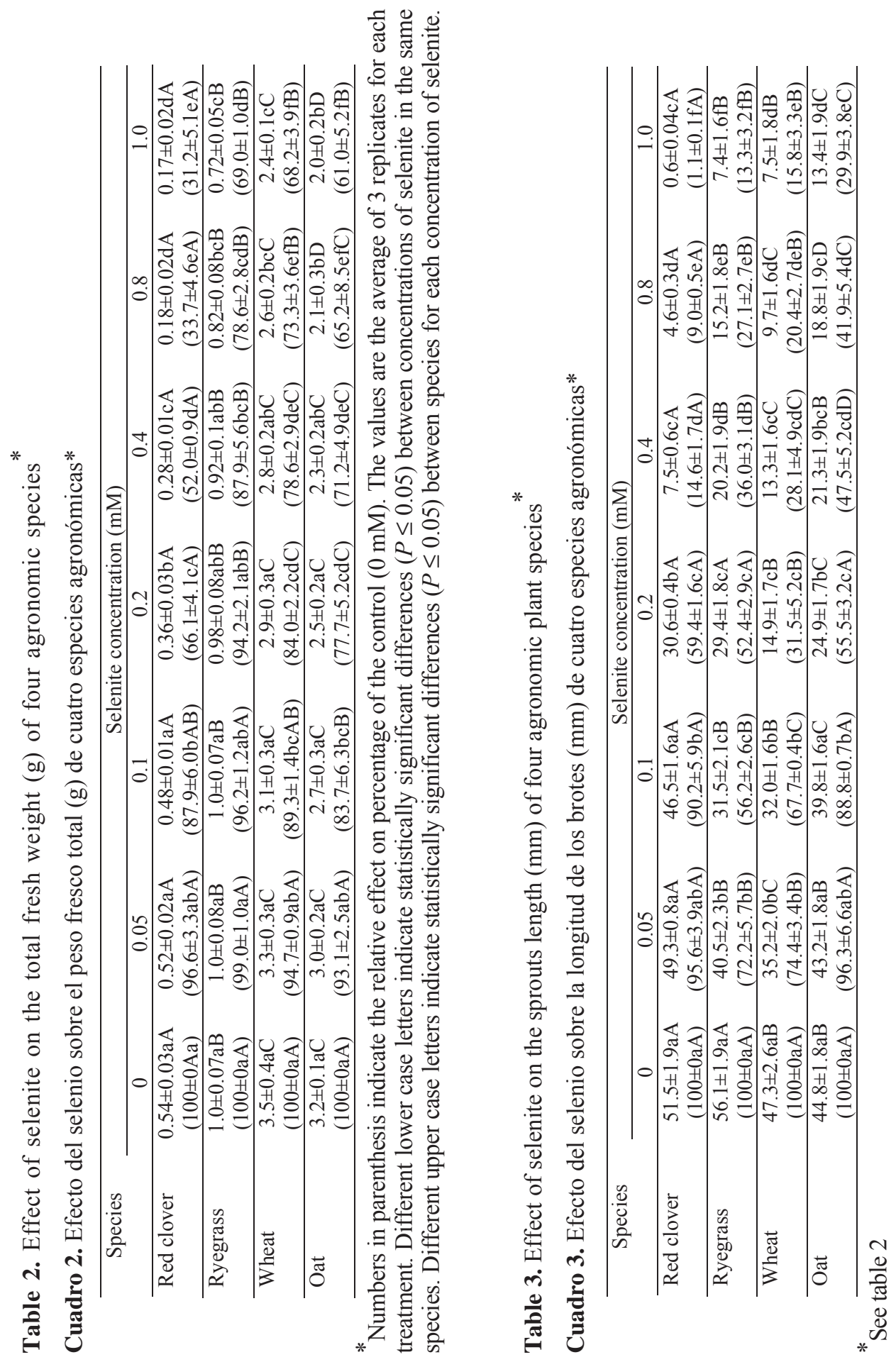


while in wheat and oat the fresh weight was similar (about $30 \% ; P \leq 0.05$ ) (Table $2)$. The effect of selenite in decreasing the total fresh weight was in the order: red clover $>$ oat $>$ wheat $>$ ryegrass.

Sprout length was also significantly reduced by the increase of selenite concentration in all plants (Table 3 ). The relative reduction was significantly higher in wheat $(32 \%$; $P \leq 0.05)$ and ryegrass $(44 \% ; P \leq 0.05)$ in the selenite concentration lower than 0.1 $\mathrm{mM}$. A less significant difference was observed in red clover and oat (about 12\%) (Table 3). In concentrations higher than 0.4 $\mathrm{mM}$, the relative reduction was highest in red clover (up to $99 \% ; P \leq 0.05$ ), and lowest in oat $(70 \% ; P \leq 0.05)$ (Table 3$)$. The effect of selenite in decreasing the length of sprout was in the order: red clover $>$ wheat $>$ ryegrass $>$ oat.

Higher plants were previously thought not to require selenium and little attention has been paid to selenium's role in the plant growth and yield (Hu et al., 2003). The question of the essentiality of selenium ( $\mathrm{Se}$ ) as a micronutrient in higher plants is unresolved and remains controversial: in trace amounts, $\mathrm{Se}$ is an essential micronutrient and has important benefits for animal and human nutrition. At high dosages, however, it may be toxic to both animals and humans (Terry et al., 2000). On the other hand, some studies have indicated that selenium affects seed germination and radicle elongation in some plant species (Carlson et al., 1989). For example, in the germination of lettuce, tomato and radish seeds, under light conditions, with the concentrations of selenium from 0 to 200 ppm, the germination percentage showed a statistically significant linear decrease with an increase in selenium concentration (Carvalho et al., 2003). No effect was found on the germination of white lupin (Lupunus sp.) at a treatment concentration of $4.6 \mathrm{mg}$ $\mathrm{Se} / \mathrm{L}$ (58.4 $\mu \mathrm{M} \mathrm{Se})$, but at the next treatment level, $46 \mathrm{mg} \mathrm{Se} / \mathrm{L}$ (584 $\mu \mathrm{M} \mathrm{Se}$ ), only $20 \%$ of the seeds germinated (Carlson et al., 1989).
In lettuce and radish seedlings, it was reported that the fresh weight decreased with increasing selenium concentration; however, in tomato, fresh weight remained constant over the range of selenium concentrations. In the germination of barley seeds in Petri dishes, both root and sprout growth was reduced by selenium (Kim et al., 2003). In this study, sprout germination and growth were retarded with the increased concentration of selenite. The results of the effect of selenite on the germination and growth of sprouts in this study showed similar tendencies to previously reported results (Carlson et al., 1989; Carvalho et al., 2003; Kim et al., 2003), although the concentrations of selenium used here are different from those used in previous studies; furthermore, this study was conducted under dark conditions.

\section{Total polyphenol substances}

Natural polyphenol and their preparations for food and nutritional supplementation or dietary purposes have received increased attention in recent years (Kroyer, 2004). With regard to the comprehensive nutritional-physiological and health promoting effects of bio-active phytonutrients, the content of polyphenols as antioxidant-active natural substances may be important in supporting the overall physiological health effects of phenol-rich plant foodstuffs (Kroyer, 2004). Polyphenolic compounds contribute to the overall antioxidant activities of the plant foods.

Total polyphenol substances per fresh weight in aqueous and ethanolic extracts of sprouts grown without selenite were highest in wheat and lowest in ryegrass (Figure 1). With the increase in the selenite concentration, total polyphenol substances in aqueous and ethanolic extracts increased in red clover, and wheat $(\mathrm{P} \leq 0.05)$. A less significant effect was observed in oat and ryegrass $(\mathrm{P}=0.682)$ (Figure 1$)$. 


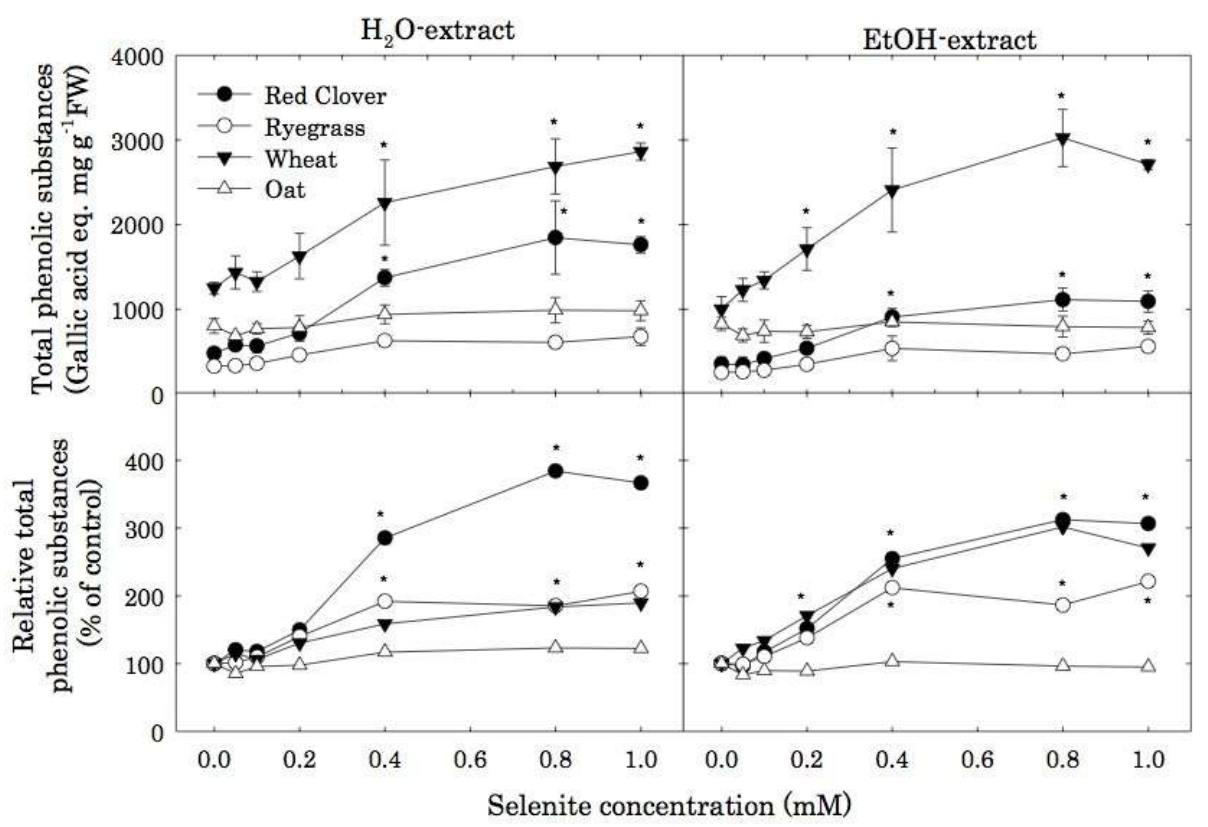

Figure 1. Effect of selenite on the total polyphenol substances in the sprouts of four agronomic plants species. The values are the average of 3 replicates for each treatment. Asterisk $(*)$ indicate statistically significant differences $(P \leq 0.05)$ between control and treatment with selenite.

Figura 1. Efecto del selenio sobre el contenido total de polifenoles en brotes de cuatro especies agronómicas. Los valores son un promedio de 3 réplicas para cada tratamiento. Asterisco $(*)$ indica diferencias estadísticamente significativas $(P \leq 0.05)$ entre el control y los tratamientos con selenio.

Polyphenol content in aqueous extract was higher in wheat than the other species (3 times; $\mathrm{P}<0.001$ ) (Figure 1). Similar results were found by other authors, suggesting that wheat cereal could be an important dietary antioxidant (Baublis et al., 2000; Kulkarni et al., 2006). Relative total polyphenol substances in aqueous extract increased significantly in red clover and approximately quadrupled $(P<0.001)$; while in ryegrass and wheat, the relative total polyphenol substances doubled $(P<0.001)$. In oat, no significant increase was observed $(P=0.068)$ (Figure 1).

In ethanolic extract, the differences between species were more evident (Figure 1). The polyphenol concentration tripled to $0.8 \mathrm{mM}$ of Se in wheat. Red clover showed about a 2 times polyphenol concentration, while this increase was not observed in ryegrass and oat (Figure 1). The relative total polyphenol substances showed a remarkable increase; in red clover and wheat ( 3 times; $P<0.001$ ), while in ryegrass the relative total polyphenol substances doubled to $0.4 \mathrm{mM}$ of Se (Figure 1). In comparing the effect of selenite in the four plant species, the total polyphenol substances were highest in wheat and lowest in oat in aqueous and ethanolic extracts. Although Kulkarni et al. (2006) found 
that the ethanol extracts showed a higher phenolic and flavonoid content than the aqueous extracts in wheat. Our results showed similar polyphenolic contents in both extracts in wheat; furthermore, this study was conducted in sprouts rather than in seedlings.

As shown in Figure 1 and Tables 3 and 4, the sprout growth was decreased by selenite concentration; polyphenol substance content per plant was less affected by selenite concentration. The sprouts grown with high concentrations of selenite accumulated high polyphenol concentrations in small-sized sprouts. The effect of the selenite on the increase of total polyphenol substance content varied as follows: red clover $>$ wheat and ryegrass $>$ oat in aqueous extract and red clover and wheat $>$ ryegrass $>$ oat in ethanolic extract. These results suggest that the effect of selenium on wheat was higher in ethanolic extract than aqueous extract, different to that observed in other species studied.

\section{DPPH radical scavenging effect}

Radical scavenging activity per fresh weight, measured by the DPPH method, in the sprouts grown without selenite, was highest in wheat and lowest in ryegrass in both aqueous and ethanolic extracts. The activities in red clover and oat were similar (Figure 2).

Due to the selenite treatment, the radical scavenging activity in wheat was greatly increased in both extracts (about 2 times; $P<0.001$ ), being slightly higher in ethanolic extract. In oat and ryegrass, a small increase was observed by selenite treatment (Figure 2).

In the aqueous extract, the relative radical scavenging activity significantly increased with the selenite concentration in wheat $(2.5$ times; $P<0.001)$ and oat $(1.5$ times; $P<0.001)$. In ryegrass, no significant difference in the relative radical scavenging activity was observed with an increase of selenite concentration $(P=0.562)$. In red clover, the activity decreased slightly, up to $0.2 \mathrm{mM}$ of selenite, and then decreased strongly (about $79 \% ; P<0.001$ ) (Figure 2).
In the ethanolic extract, the relative radical scavenging in wheat and ryegrass were significantly increased with the increase of selenite concentration (about $150 \% ; P<$ $0.001)$. In oat, an increase in relative value was also observed ( $48 \% ; P<0.001)$, but values were always lower than in wheat and ryegrass (Figure 2).

In the comparison of the effect of selenite in the four plant species, the relative radical scavenging values were highest in wheat and lowest in red clover in aqueous and ethanolic extracts (Figure 2), being higher in ethanolic extract. The effect of selenite on the increase of radical scavenging activity varied as follows: wheat $>$ oat $>$ ryegrass $>$ red clover in aqueous extract, and wheat $>$ ryegrass $>$ oat $>$ red clover in ethanolic extract.

Until further research is conducted, no other data exist that address the effect of selenium on radical scavenging and polyphenol concentrations in sprouts grown with selenite under dark conditions. Under light conditions, it has been previously reported that the antioxidant capacity of seeds was lower than that of sprouts, indicating a fast biochemical synthesis of antioxidants during the germination processes in the seeds of broccoli, quinoa and amaranth (Jung et al., 2006). Cartes et al. (2005) determined that selenite was more efficient that selenate in promoting GSHPx activity in ryegrass, and Cartes et al. (2006) demonstrated that the antioxidant ability of Se was decreased by an antagonistic relationship between selenite and sulfate in ryegrass.

\section{Inhibition activity of lipid peroxidation}

Inhibition activity by fresh weight, measured by the linoleic acid oxidation method, in the sprouts grown without selenite, was comparatively higher in oat and wheat and lower in ryegrass and red clover in aqueous extracts (Figure 3). Upon treatment with selenite, the activity in aqueous extracts was increased in all plant species. A small difference between plant species in the effect of selenite on the relative inhibition of the 
lipid peroxidation values was observed in the aqueous extract (Figure 3 ). The relative inhibition of the lipid peroxidation values in aqueous extracts were similar between species $(P=0.455)$ (Figure 3$)$.

In ethanolic extracts, the inhibition of the lipid peroxidation in wheat $(25 \% ; P<0.001)$ and ryegrass $(60 \% ; P<0.001)$ increased with the increase in selenite concentration; whereas in oat and red clover, a lesser effect was observed with up to $0.1 \mathrm{mM}$ of selenite (Figure 3). The inhibition of the lipid peroxidation decreased in the concentration above $0.2 \mathrm{mM}$ of selenite in oat $(30 \% ; P<$ $0.001)$ and above $0.4 \mathrm{mM}$ in red clover $(60$ $\% ; P<0.001)$. The relative inhibition of the lipid peroxidation values in ethanolic extracts significantly increased in ryegrass $(90 \%$; $P<0.001)$ and wheat $(40 \% ; P<0.001)$, while values decreased in oat and red clover (Figure 3). In ethanolic extracts, the increasing effect of selenite on relative value was greater in ryegrass than in wheat. In comparing the effects of selenite in the four plants, a small difference was observed in the relative inhibition of the lipid peroxidation values between plants in aqueous extract; while greater differences were observed in ethanolic extracts (Figure $3)$. The effect of the selenite on the increase of lipid peroxidation inhibition was less varied in aqueous extracts; while the effect of selenite in ethanolic extract was as follows: ryegrass $>$ wheat $>$ oat $>$ red clover. In this study, the germination percentages at the high selenite concentrations were lower in red clover than in the other plants. In addition, sprout growth was severely retarded by selenite

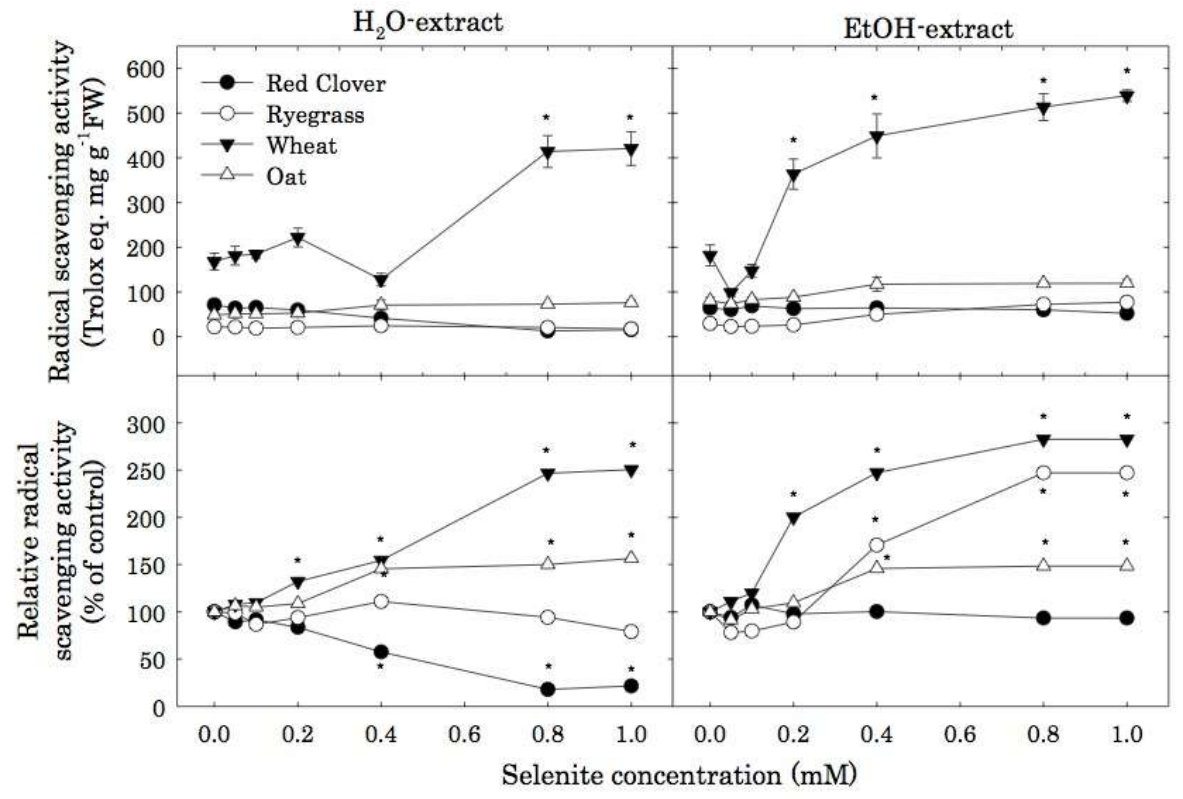

Figure 2. Effect of selenite on the DPPH radical scavenging activity in the sprouts of four agronomic plants species. The values are the average of 3 replicates for each treatment. Asterisk $(*)$ indicate statistically significant differences $(P \leq 0.05)$ between control and treatment with selenite.

Figura 2. Efecto del selenio sobre la remoción de radicales libres en brotes de cuatro especies agronómicas. Los valores son un promedio de 3 réplicas por cada tratamiento. Asterisco $(*)$ indica diferencias estadísticamente significativas $(P \leq 0.05)$ entre el control y los tratamientos con selenio. 


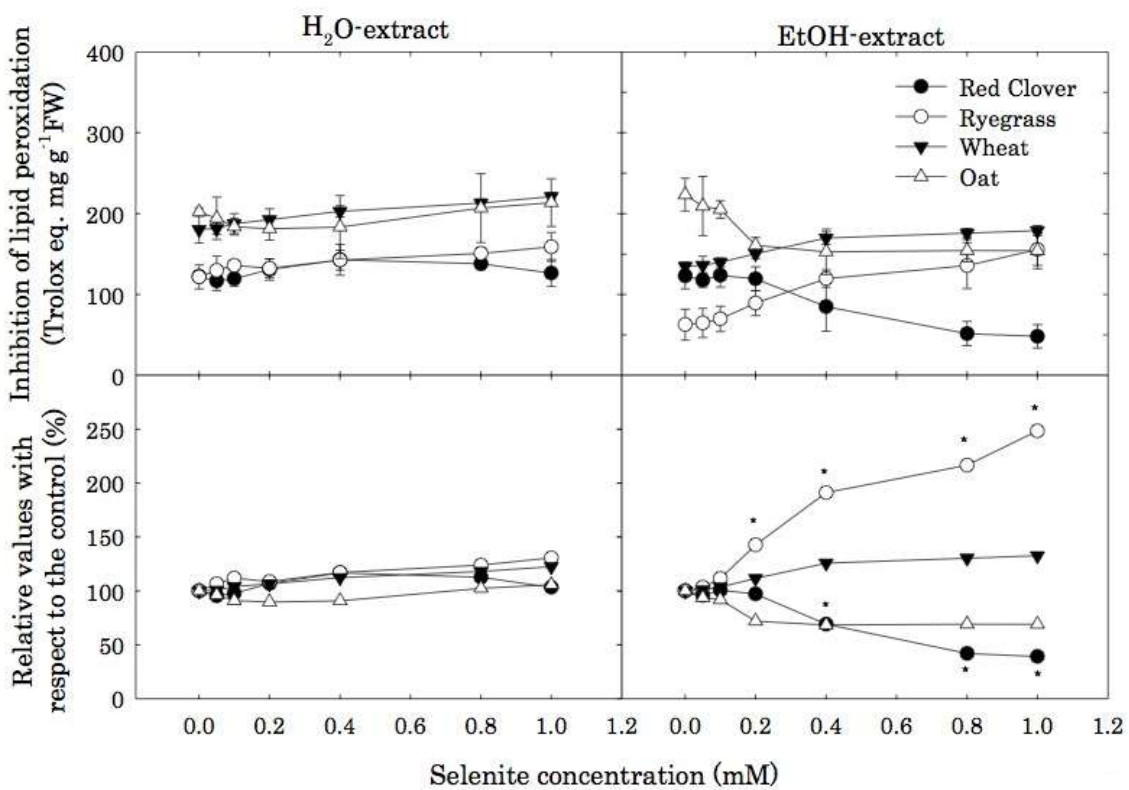

Figure 3. Effect of selenite on the inhibition of lipid peroxidation activity in the sprouts of four agronomic plants species. The values are the average of 3 replicates for each treatment. Asterisk (*) indicate statistically significant differences $(P \leq 0.05)$ between control and treatment with selenite.

Figura 3. Efecto del selenio sobre la inhibición de la actividad de peroxidación de lípidos en brotes de cuatro especies agronómicas. Los valores son un promedio de 3 réplicas para cada tratamiento. Asterisco $(*)$ indica diferencias estadísticamente significativas $(P \leq 0.05)$ entre el control y los tratamientos con selenio.

treatment. Very low activity of lipid peroxidation in the high concentration of selenite may be related to the retarded growth of the sprouts.

\section{Effect of selenite on the polyphenol content and antioxidant activity}

It is well known that polyphenol compounds - including flavonoids - are responsible for the potential antioxidant activity and radical scavenging capacity of food (Kroyer, 2004; Naczk and Shahidi, 2006; Kulkarni et al., 2006; Spingo and Faveri, 2007). Phenolic substances are reported to have beneficial effects on human health and, moreover, plants contain significant amounts of polyphenol substances that are known for their potential bioactive antioxidant properties and radical scavenging capacity (Kroyer, 2004).
Concerning the effect of selenium on the polyphenols, the content of selenium and polyphenol were greatly increased by foliar application of selenium-enriched fertilizer in green tea leaves. Selenium-enriched green tea exhibited significantly higher antioxidant activity than regular green tea (Xu and $\mathrm{Hu}$, 2004). When selenium is applied to the soil of rice plants grown in the field, the radical scavenging activity in the aqueous extracts of the harvested rice grain increased with the increase of the selenium concentration; whereas a decrease was observed in ethanolic extracts (Xu and $\mathrm{Hu}, 2004)$. These results indicate that selenium increased the polyphenol content in plants; however, the antioxidant capacity induced by selenium did not always correspond with the concentration of polyphenol. 
It is already known that red clover is a rich source of isoflavones and that it contains significant amounts of polyphenol substances (Kroyer, 2004). However, the antioxidant capacity, measured by the DPPH method, in sprouts of red clover grown under light conditions was much lower than in sprouts of broccoli and dandelion (Jung et al., 2006).

The main antioxidant in sprouts of red clover is reported to be clovamide, a compound that takes a very long time to react with the test radical DPPH. The inclusion of the behavior kinetics of the antioxidant reducing process to determine the antioxidant capacity allows the main antioxidant present in a sample to be identified (Jung et al., 2006). Since the antioxidants are concentrated in the outer layers of the kernel in oat and in the bran of wheat grain, these antioxidant-rich portions can also be used as a healthy food material (Peterson, 2001; Liyana-Pathirana and Shahidi, 2007).

Monophenols are known to be less efficient than polyphenols in their antioxidant activity. Some chemical reactions following their oxidation are concerned with the radical scavenging activity of polypohenolic antioxidants, and the correlations between the oxidation potentials of polyphenols and their antioxidant activities have been observed only for a certain family of antioxidants having a common structure (Hotta et al., 2002).

In wheat plants, it has been shown that applied selenite causes activation of polyphenol oxidase only at low concentrations $(0.05$ and $0.15 \mathrm{mM} / \mathrm{kg}$ soil), but at higher concentration of selenite an inhibition of polyphenol oxidase $(0.45$ $\mathrm{mM} / \mathrm{kg}$ soil) was observed (Nowak et al., 2004). Further investigation is necessary to determine the effect of selenite on polyphenol oxidase activity in other species.

The selenium concentrations in sprouts were not determined in this study, but in ryegrass, it increased with the concentration of selenite applied to soil in pots (Cartes et al., 2005, 2007). Barley seedlings also accumulate selenite in the form of selenomethyonine (Kim et al., 2003). Selenium concentration in rice grain was increased by the foliar application of selenium (Xu and $\mathrm{Hu}, 2004$ ).

These results demonstrate that plants can uptake and accumulate selenium. A convincing argument can be made for augmenting the food supply with selenium, and selenium-enhanced plants may be the best means of improving the diseases induced by selenium deficiency (Finley, 2005).

Although further investigations are necessary to address the function of phenolic antioxidative activity in human, animal and plant food chains, considering the beneficial nutritional-physiological and healthimproving effects of phenolic substances and selenium, the sprouts of wheat and ryegrass grown with selenite under dark conditions could be considered a potent and functional (antioxidant and radicalscavenging active) food ingredient or dietary food supplement for both human and animals.

\section{ACKNOWLEDGEMENTS}

This research was supported by the Senior Voluntary Program of Japanese International Cooperation Agency during 2005 and 2007 and FONDECYT Project \# 1061262. The authors wish to thank Prof. Rolando Demanet and Prof. Juan Carlos Garcí'92a of the Instituto de Agroindustria, Universidad de La Frontera, Chile, for supplying of seeds of ryegrass and wheat, respectively.

\section{REFERENCES}

BAUBLIS AJ, LU CH, CLYDESDALE FM AND DECKER EA. 2000. Potential of Wheat-Based Breakfast Cereals as a Source of Dietary Antioxidants. J Am College Nutr 19(3):308S-311S.

CARLSON GL, KAPLAN DI AND ADRIANO DC. 1989. Effects of selenium on germination and radicle elongation of selected agronomic species. Environ Exp Bot 29(4):493498. 
CARTES P, GIANFREDA L AND MORA ML. 2005. Uptake of selenium and its antioxidant activity in ryegrass when applied as selenate and selenite forms. Plant Soil 276:359-367.

CARTES P, SHENE C, MORA ML. 2006. Selenium distribution in ryegrass and its antioxidant role as affected by sulfur fertilization. Plant Soil 285:187-195.

CARVALHO KM, GALLARDOWILLIAMS MT, BANSON RF AND MARTIN DF. 2003. Effects of selenium supplementation on four agricultural crops. J Agric Food Chem 51(3):704-709.

CHYAU CC, KO PT AND MAU JL. 2006. Antioxidant properties of aqueous extract from Terminalia catappa leaves. Zeitschrift fur Naturforschung (LWT) 39:1099-1108.

FINLEY JW. 2005. Selenium accumulation in plant foods. Nutr Rev 63(6):196202.

FOTI M, PIATELLI M, TIZIANA BM, GIUSEPPE R. 1996. Flavonoids, Coumarines, and Cinnamic acids as antioxidants in a mecellar system. Structure-activity relationship. J Agric Food Chem 44: 497-501.

GISSEL-NIELSEN G, GUPTA UC, L A M A N D M A N D WESTERMARCK T. 1984. Selenium in soils and plants and its importance in livestock and human nutrition. Adv Agron 37:397-460.

GUPTA UC AND WATKINSON JH. 1985. Agricultural significance of selenium. Outlook Agric 14:183-189.

GUPTA UC AND GUPTA SC. 2000. Selenium in soils and crops, its deficiencies in livestock and humans: Implications for management. Commun Soil Sci Plant Anal 31:1791-1807.

HARTIKAINEN H AND XUE T. 1999. The promotive effect of selenium on plant growth as trigged by ultraviolet irradiation. J Environ Qual 28:13721375.
HO CT, CHEN Q, SHI H, ZHANG KQ, ROSEN RT. 1992. Antioxidative effect of polyphenol extract prepared from various Chinese teas. Prev Med 21:520- 525 .

HOTTA H, NAGANO S, UEDA M, TSUJINO Y, KOYAMA J, OSAKAI T. 2002. Higher radical scavenging activities of polyphenolic antioxidants can be ascribed to chemical reactions following their oxidation. Biochem Biophys Acta 1572:123-132.

HU Q, XU J, PANG G. 2003. Effect of selenium on the yield and quality of green tea leaves harvested in early spring. J Agric Food Chem 51(11):3379-3381.

JOHNSSON L. 1992. Selenium in Swedish soils. Factors influencing soil content and plant uptake. Ph.D. Thesis. Department of Soil Sciences, Swedish University of Agricultural Sciences. Reports and Dissertations No. 10.

JUNG K, RICHTER J, KABRODT K, LUCKE IM, SCHELLENBERG I AND HERRING TH. 2006. The antioxidantative power AP-A new quantitative time dependent (2D) parameter for the determination of antioxidant capacity and reactivity of different plants. Spectrochimica Acta Part A 63:846-850.

KANNER J, FRANKEL E, GRANIT R, GERMAN B, KINSELLA JE. 1994. Natural antioxidants in grapes and wines. J Agric Food Chem 42:64-69.

KIM YB, GARBISU C, PICKERING IJ, PRINCE RC, GEORGE GN, CHO MJ, WONG JH AND BUCHANAN BB. 2003. Thioredoxin $h$ overexpressed in barley seeds enhances selenite resistance and uptake during germination and early seedling development. Planta 218(2): 186-191.

KOO MWL, CHO CHH. 2004. Pharmacological effects of green tea on the gastrointestinal system. Eur J Pharm 500 :177- 185. 
KROYER GT. 2004. Red clover extract as antioxidant active and functional food ingredient. IFSET 5:101-105.

KULKARNI SD, TILAK JC, ACHARYA R, R A J URK A R N S, DEVASAGAYAM TPA AND REDDY AVR. 2006. Evaluation of the Antioxidant Activity of Wheatgrass (Triticum aestivum L.) as a Function of Growth under Different Conditions. Phytother Res 20:218-227.

LIYANA-PATHIRANA CM AND SHAHIDI F. 2007. Antioxidant and free radical scavenging activities of whole wheat and milling fractions. Food Chem 101(3): 1151-1157.

MORA ML, PINILLA L, ROSAS A AND CARTES P. 2007. Selenium uptake and its influence on the antioxidantive system of white clover as affected by lime and phosphorus fertilization. Plant Soil DOI 10.1007/s11104-007-9494$\mathrm{z}$ (in press).

NACZK M AND SHAHIDI F. 2006. Phenolics in cereals, fruits and vegetables: Occurrence, extraction and analysis. J Pharm Biomed Anal 41:1523-1542.

NOWAK J, KAKLEWSKI K AND LIGOCKI M. 2004. Influence of selenium on oxidoreductive enzymes activity in soil and in plants. Soil Biol Biochem 36(10): 1553-1558.

PETERSON DM. 2001. Oat antioxidants (Mini review). J Cereal Sci 33(2):115129.

PIETTA P, SIMONETTI P, MAURI P. 1998. Antioxidant activity of selected medicinal plants. J Agric Food Chem 46:4487-4490.

SATO M, RAMARATHNAM N, SUZUKI Y, OHKUBO T, TAKEUCHI M, OCHI H. 1996. Varietal differences in the phenolic content and superoxide radical scavenging potential of wines from different sources. J Agric Food Chem 44:41-47.
SERAFINI M, GHISELLI A, FERROLUZZI A. 1996. In vivo antioxidant effect of green and black tea in man. Eur J Clin Nutr 50:28-32.

SINGLETON VL AND ROSSI JA JR. 1965. Colorimetry of total phenolics with phosphormolybdicphosphotungstic acid reagents. Am J Enol Vitic 16(3):144-158.TAYLOR PW, HAMILTON-MILLER JMT, STAPLETON PD. 2005. Antimicrobial properties of green tea catechins. Food Sci Tech Bull Funct Foods 2(7):71-81.

TERRY N, ZAYED AM, DE SOUZA MP, TARUN AS. 2000. Selenium in higher plants. Annu Rev Plant Physiol Plant Mol Biol 51:401-32.

VINSON JA, DABBAGH YA, SERRY MM, JANG J. 1995. Plant flavonoids, especially tea flavanols, are powerful antioxidants using an in vitro oxidation model for heart disease. J Agric Food Chem 43:2800-2802.

WANG H, CAO G, PRIOR RL. 1996. Total antioxidant capacity of fruits. J Agric Food Chem 44:701-705.

WITTWER A, ARANEDA P, CEBALLOS A, CONTRERAS P, ANDAUR M AND BÖHWALD H. 2002. Actividad de glutatión peroxidasa (GSH-Px) en sangre de bovinos a pastoreo de la IX Región, Chile y su relación con la concentración de selenio en el forraje. Arch Med Vet 34:49-57.

XU J, ZHU SH, YANG F, CHENG L, HU Y, PAN G AND HU Q. 2003. The influence of selenium on the antioxidant activity of green tea. J Sci Food Agric 83(5):451-455.

SPINGO G AND FAVERI DMD. 2007. Antioxidants from grape stalks and marc: Influence of extraction procedure on yield, purity and antioxidant power of the extracts. J Food Enginer 78:793801.

XU J AND HU Q. 2004. Effect of foliar application of selenium on the antioxidant activity of aqueous and ethanolic extracts of selenium-enriched rice. J Agric Food Chem 52:17591763. 